Published in Social Science Research

https://doi.org/10.1016/j.ssresearch.2019.01.002

\title{
Support of Workplace Diversity Policies: The Role of Race, Gender, and Beliefs about Inequality
}

\author{
William J. Scarborough \\ University of Illinois at Chicago \\ University of North Texas \\ Danny Lambouths III \\ University of Illinois at Chicago \\ Allyson L. Holbrook \\ University of Illinois at Chicago
}

\section{Abstract}

Workplace diversity policies are more effective when they are supported by managers and workers, but there is little direct evidence on how people feel about these policies or why they hold certain opinions. In this study, we analyze data from a survey experiment designed to assess public opinion about a range of workplace diversity policies. We examine how support for these policies among employed respondents varies by race, gender, and by the targeted population (i.e. whether the policies aim to improve the workplace representation of women or racial minorities). Using OLS regression models to analyze a diverse sample of employed persons participating in the survey, we find that women, blacks, and Latina/os are more supportive of diversity policies than men and whites, and a substantial portion of these gender/race differences can be explained by group-differences in the belief that discrimination causes inequality. In addition, we find that respondents report lower levels of support for workplace policies when these policies are framed as a mechanism to increase diversity than when they are framed as being needed to address discrimination or if no justification is given for the policy. Our findings highlight the role of 
inequality beliefs in shaping worker support for diversity policies, suggesting directions for future research on how such beliefs are developed.

\section{INTRODUCTION}

Racial diversity and equality are important social issues in our world today. One place where efforts to improve diversity and address racial inequality have had a profound effect is in the workplace (Dobbin, 2009; Kalev, Dobbin, and Kelly, 2006). Companies are pumping more money and devoting more energy than ever before into efforts to increase and support workplace diversity (Dobbin, 2009; Scarborough, 2017). Not only do more diverse firms perform better than their homogenous counterparts (Herring, 2009), but failure to address internal issues of diversity can hurt a company's reputation and be expensive - with lawsuits costing some companies millions of dollars (Merrill Lynch has paid nearly half a billion dollars in discrimination-related lawsuits since the 1990s [Dobbin and Kalev, 2016]).

These pressures have led many companies to adopt policies aimed at encouraging and supporting diversity. These policies take on a wide range of forms, such as diversity training, mentorship programs, and/or the establishment of diversity offices. As diversity policies have become a vital part of U.S. companies in recent history (Edelman et al., 2011), scholars have given more attention to these programs from an organizational perspective (Dobbin, Schrage, and Kalev, 2015; Kalev, Dobbin, and Kelly, 2006). We now have a wealth of evidence about what types of diversity programs work and which ones do more harm than good (Correll et al., 2014; Kaiser et al., 2013; Kalev, Dobbin, and Kelly, 2006). We also know that some companies may use diversity policies symbolically, primarily to protect themselves from lawsuits or to enhance their company's reputation, rather than making a genuine effort to improve worker inclusion (Edelman, 2002; Edelman et al., 2011; Edelman, Uggen, and Erlanger, 1999). 
Despite their widespread use, however, we actually know very little about how members of the general public feel toward some of the most commonly adopted diversity policies. While the public opinion literature has devoted significant attention towards individuals' attitudes on affirmative action ${ }^{1}$ in the U.S. (see Arcidiacono, Lovenheim, and Zhu, 2015; Crosby, Iyer, and Sincharoen, 2006; Harper and Reskin, 2005; Krysan, 2000; and Sears, Sidanius, and Bobo, 2000 for reviews), few workplaces use the language of affirmative action to describe their workplace policies (Bielby, 2000). Furthermore, although there are many different types of workplace diversity policies used today, the vast majority of them do not fit the prototypical and controversial preferential hiring programs that people may think of when they are asked about affirmative action (Bielby, 2000). Indeed, typical race-based affirmative action programs have been banned at public universities in some states. Instead of affirmative action programs, people work in companies that have diversity trainings, diversity task forces, managerial accountability structures, and targeted recruitment strategies.

This may seem like a simple difference in nomenclature, but the term affirmative action has become highly politicized and polarizing. There is evidence from several other domains that the same policy described using a highly politicized term may be interpreted differently than the same policy described using less politicized terminology. For example, support for increased spending on "welfare" (a term that became highly racialized during the 1980's) is more strongly predicted by racial attitudes than is support for spending on "assistance to the poor" (Holbrook et al., forthcoming). Similarly, Obama's involvement in passing the Affordable Care Act has led to partisan polarization of attitudes toward health care reform, particularly when Obama is linked to

\footnotetext{
${ }^{1}$ Affirmative action is the common term used in the U.S. to refer to programs aimed at combatting gender/race discrimination and promoting equal employment and educational opportunities (see Crosby, Iyer, and Sincharoen, 2006 for extended discussion on the definition of affirmative action).
} 
the reform (e.g., Tesler, 2012). This may help to explain why people (particularly Republicans) evaluate the Affordable Care Act negatively, but evaluate specific elements of the bill positively (e.g., Gross et al., 2012). Workplace diversity policies are typically not called affirmative action, they do not look like the prototypical preference-based hiring policies associated with the term, and affirmative action is a racialized and politicized term. As a result, it is unclear how much responses to survey questions about affirmative action may tell us much about how the public thinks about the types of workplace diversity policies that are routinely adopted and implemented today. We address this by assessing directly whether known predictors of attitudes toward affirmative action also predict attitudes toward workplace policies.

Furthermore, unlike affirmative action - which is strongly linked to simple preferencebased hiring practices, businesses and other workplaces today have a range of possible policies that can be implemented in order to address workplace inequality. Although researchers have begun to examine mean differences in support for different policies (e.g., Bielby, Krysan, \& Herring, 2014), little research has examined the underlying factor structure of support for different types of workplace policies. For example, is support for more drastic policies (e.g., targeted recruitment or numerical quotas) correlated with support for voluntary programs that leave many workers unaffected (e.g., voluntary training or mentorship)? We address this in the current research by assessing whether support for different workplace diversity policies reflects a single attitudinal construct, or if there are multiple underlying dimensions of employees’ opinions toward these policies.

In this paper, we analyze data from a survey experiment that asked respondents about their attitudes ${ }^{2}$ toward eight common diversity initiatives. First, we focus on respondents' overall

\footnotetext{
${ }^{2}$ In this study, we use the established definition for attitude as "a psychological tendency that is expressed by evaluating a particular entity with some degree of favor or disfavor" (Eagly \& Chaiken, 1993, p. 1). Because our
} 
level of support for workplace diversity policies rather than evaluative assessments of whether such policies are needed or useful, we also target respondents who are employed, since these respondents are most likely to be familiar with and affected by workplace policies to address diversity. In a general sense, this paper provides a 'pulse check' of how people feel about workplace diversity policies today. Secondly, the design of the survey experiment allows us to examine whether support is affected by the target of the policy (women or racial minorities) and the justification for why the policy is needed (improve diversity/address discrimination/none). Third, we analyze predictors of workplace policy attitudes, including race, gender, and beliefs about the causes of inequality.

We begin our discussion by reviewing existing knowledge about workplace diversity policies. Then, we summarize key lessons gleaned from the literature examining individuals' attitudes toward affirmative action before introducing the current study. Next, we describe the methods of the current study. We analyze these data by first examining whether respondent support for a range of workplace policies reflects one (or more) underlying dimensions. We present descriptive statistics for key independent and dependent variables, including support for workplace policies designed to address both race and gender discrimination. We then examine predictors of support for these workplace policies, including race/ethnicity, gender, and beliefs about the causes of inequality (including causes like discrimination and differential access to training and education). Finally, we examine the extent to which beliefs about the causes of inequality (i.e., attributions for inequality) mediate or explain race/ethnic and gender differences in support for policies to ameliorate inequality.

focus is on respondents' attitudes toward diversity policies, which they may favor or disfavor, we use the terms "attitude" and "support" interchangeably, since they are synonymous in this particular context. 


\section{WORKPLACE DIVERSITY/INCLUSION POLICIES}

In recent years, researchers have devoted attention to the study of workplace diversity programs (Correll et al., 2014; Heilman, 2001; Kalev, 2009; Kalev and Deutsch, 2018; Kalev, Dobbin, and Kelly, 2006; Kelly et al., 2010; Kelly, Moen, and Tranby, 2011). When used effectively, diversity policies improve workplace equity (Correll et al., 2014; Kelly et al., 2010; Kelly, Moen, and Tranby, 2011) and boost employee performance (Ely and Thomas, 2001; Herring, 2009; Hubbard, 2004). Some workplace policies are more effective at improving diversity than others (Kalev, Dobbin, and Kelly, 2006) and some firms may institute diversity policies to protect themselves from lawsuits rather than as a genuine effort to improve equity (Dobbin, 2009; Edelman et al., 2011; Edelman, 2002; Edelman, Uggen, and Erlanger, 1999).

While we know quite a bit about the effectiveness (Kalev, Dobbin, and Kelly, 2006) and the rationale behind the design of diversity policies (Bielby 2000; Correll et al., 2014; Edelman et al., 2011; Edelman et al., 1999; Wynn and Correll, 2018), we know little about how people feel toward them. This is a particularly large omission, because these policies are more effective when supported by employees and organizational leaders (Dobbin and Kalev, 2016; Dobbin, Schrage, and Kalev, 2015; Kalev, Dobbin, and Kelly, 2006).

Recent research strongly suggests that support for diversity policies is a critical component to their success. Yet, we have little evidence about how people feel about diversity policies or why they hold certain attitudes. Despite the attention devoted to the design and effectiveness of diversity policies, little has been directed towards understanding employees' support of these initiatives. In contrast, there has been substantial research on public opinion about affirmative action. The generalizability of this research is unknown, however, because diversity policies are rarely called "affirmative action" and they almost never take the form of 
preferential hiring ${ }^{3}$ that is commonly associated with the term "affirmative action". To bridge these two bodies of research, we test whether the characteristics that predict attitudes toward affirmative action also influence attitudes towards workplace diversity initiatives.

\section{ATTITUDES TOWARD AFFIRMATIVE ACTION}

Scholars have examined the determinants of individuals' support or opposition to affirmative action since shortly after the policy was first introduced in the 1960s (Snyder and Swann, 1976). Since that time, three primary determinants of individuals' attitudes toward affirmative action have emerged. First, we continually find differences in support across political orientation. Conservatives tend to oppose affirmative action, while liberals show the most support and moderates are somewhere in-between (Sniderman and Carmines, 1997; Sniderman, Crosby, and Howell, 2000). Second, there are major race and gender differences in support for affirmative action, with whites and men showing the greatest opposition and non-whites and women expressing the greatest support (Bobo, 1998; Bobo and Kluegel, 1993; Steeh and Krysan, 1996). Many scholars have argued that these race and gender differences are the result of varying perceptions of group-interest, since whites and men may feel they don't benefit from the policy, they oppose it, while minorities and women may show support because of an interest in improving their group's position (Beaton and Tougas, 2001; Sidanius, Pratto, and Bobo, 1996). Finally, an expanding body of research has found that racial attitudes, race consciousness, and beliefs about race/gender inequality influence individuals' support of affirmative action. While it may not be surprising that whites who hold racist attitudes and men who hold sexist attitudes oppose affirmative action (Kane and Whipkey, 2009; Rabinowitz et al., 2009; Sears et al., 1997; Shteynberg et al., 2011, Tuch and Hughes, 2011), individuals' beliefs about inequality and their

\footnotetext{
${ }^{3}$ Quotas are unlawful in the United States except to remedy past discrimination (Bielby 2000).
} 
consciousness of gender/race issues also affect how they feel about affirmative action (Boeckmann and Feather, 2007; Dawson 2001; Kane and Whipkey, 2009; Vescio et al., 2016). Consistently, studies find that when individuals feel that racial/gender discrimination disadvantages minorities/women and privileges whites/men, they are more likely to support affirmative action. While average levels of these beliefs vary across race and gender groups, with men and whites reporting lower beliefs in discrimination than women and non-whites (Cotter, Hermsen, and Vanneman, 2011; Hunt, 2007), higher levels of these beliefs have been associated with increased support for affirmative action across race and gender groups.

One limitation of previous research on attitudes toward affirmative action is that it relies on respondents' common assumption of what affirmative action looks like. Instead of measuring respondents' attitudes toward different types of affirmative action programs, previous research has overwhelmingly relied on survey questions that ask about respondents' opinions toward "affirmative action" broadly conceived. The advantage of this approach is that it saves time and effort - since most individuals have some idea of what affirmative action is, surveys can reduce respondent fatigue by using the phrase "affirmative action" rather than explaining details of the specific policy. But very few workplaces call their policies "affirmative action" in order to avoid political backlash from employees who strongly oppose this measure (Bielby 2000). As a result, individuals' attitudes toward affirmative action are less relevant to actual workplace policies and more reflective of their opinions toward the specific political buzzword of "affirmative action" that has taken on racialized and gendered meanings.

In this study, we bridge two bodies of literature to examine how people feel towards workplace diversity policies and why they hold those attitudes. As noted above, previous literature on diversity policies has found that programs with employee support are the most 
successful at improving diversity. Yet, we do not currently know how people in today's workforce feel towards diversity policies. While previous research on attitudes toward affirmative action may give us some idea of how people feel toward employment policies, its relevance is less than ideal because workplaces rarely adopt the terminology of affirmative action and instead use an array of specific diversity policies and structures. In this study, we apply key insight from previous research on attitudes toward affirmative action to examine individuals' opinions towards some of the most common workplace diversity policies. We are particularly interested in examining racial/gender differences and the effects of racial/gender attitudes. $^{4}$

In this study, we ask the following questions:

- How are individuals' race and gender associated with their support for diversity policies?

- How are individuals' beliefs in the sources of race/gender/class inequality associated with support for workplace diversity policies and are there race/gender differences in this relation?

- Do differences in individuals' beliefs about the sources of race/gender/class inequality explain race and gender differences in support for workplace diversity policies?

To answer these questions, we use a unique survey experiment that measured individuals' support for several diversity policies, randomly varying the target of the policy (racial minorities/women) and the justification of the policy (to improve diversity/to address discrimination/no justification given) as between-subjects variables. The survey also included a

\footnotetext{
${ }^{4}$ While political orientation has been found to be influential in attitudes toward affirmative action, it is less relevant to workplace policies that are not widely seen as a political issue. Furthermore, examining racial/gender attitudes provides a more pragmatic approach, since these attitudes are often the focus of employee trainings while political orientations are seen as separate from the work domain. Nonetheless, we include political orientation in our analysis, but reserve our focus on specific racial/gender attitudes.
} 
number of items measuring respondents' beliefs about the sources of race/gender inequality. The design of this study allows us to test whether individuals are more supportive of workplace diversity policies aimed at supporting women or racial minorities, to test whether the justification for diversity policies affects support, to test whether evaluations of different workplace diversity policies can be combined into a reliable index, and to examine whether beliefs about inequality predict support for workplace diversity policies.

\section{STUDY DESIGN}

We analyze data from Bielby’s (2014) study, “Americans' Support for Workplace Interventions Combating Racial and Gender Bias: The Impact of Policy Justification and Inequality Beliefs". The study used a 2 X 3 factorial design that randomly exposed respondents to one of two policy targets and one of three policy justifications. The design of the study and order of the questions are illustrated in Figure 1, where $C$ represents socio-demographic controls and other non-focal independent variables that were asked to all respondents, $R$ is random assignment, $T$ represents the randomly assigned target conditions (policies designed to address racial or gender inequality), $J$ is the randomly assigned policy justification (to improve diversity, address discrimination, or none), $O$ is the outcome measuring individuals' support for the policy, and $A$ is the measure of respondents' beliefs about either race or gender inequality (depending on condition). 


\begin{tabular}{|c|c|c|c|c|c|}
\hline \multirow[b]{2}{*}{$\mathrm{C}$} & \multicolumn{5}{|c|}{ Figure 1: Design of Experiment } \\
\hline & $\mathrm{R}$ & $\mathrm{T}_{\text {race }}$ & $\mathrm{J}_{\text {discrimination }}$ & $\mathrm{O}$ & $A_{\text {race }}$ \\
\hline $\mathrm{C}$ & $\mathrm{R}$ & $\mathrm{T}_{\text {race }}$ & $\mathrm{J}_{\text {diversity }}$ & $\mathrm{O}$ & $A_{\text {race }}$ \\
\hline $\mathrm{C}$ & $\mathrm{R}$ & $\mathrm{T}_{\text {race }}$ & $\mathrm{J}_{\text {none }}$ & $\mathrm{O}$ & $\mathrm{A}_{\text {race }}$ \\
\hline $\mathrm{C}$ & $\mathrm{R}$ & $\mathrm{T}_{\text {gender }}$ & $\mathrm{J}_{\text {discrimination }}$ & $\mathrm{O}$ & Agender \\
\hline $\mathrm{C}$ & $\mathrm{R}$ & $\mathrm{T}_{\text {gender }}$ & $\mathrm{J}_{\text {diversity }}$ & $\mathrm{O}$ & Agender \\
\hline $\mathrm{C}$ & $\mathrm{R}$ & $\mathrm{T}_{\text {gender }}$ & $\mathbf{J}_{\text {none }}$ & $\mathrm{O}$ & $\mathrm{A}_{\text {gender }}$ \\
\hline
\end{tabular}

As illustrated in Figure 1, there were six experimental conditions to which respondents were randomly assigned. This design allows us to isolate the effects of policy target and justification by creating the conditions to test whether, all else being equal, respondents feel differently about workplace policies if they are targeted towards racial minorities or women, or if they are given various types of justifications. Furthermore, the conditions of $A$, respondents' beliefs about race or gender inequality, depended on whether respondents were assigned the gender or race target earlier in the survey. Respondents assigned the race target in their assessments of workplace policy were asked about their beliefs on race inequality, and respondents assigned the gender target were asked about their beliefs on gender inequality. The order of questions within A was also rotated across respondents. ${ }^{5}$

\footnotetext{
${ }^{5} O$ was asked prior to $A$ to reduce the potential that questions about inequality would prime individuals' responses to the policy support items, since inequality beliefs may convey value and are therefore more subject to social desirability bias. Nonetheless, there remains potential for order effects when predicting policy support $(O)$ with beliefs about inequality $(A)$ because participants may respond to the belief items in ways that are consistent with their reported support for policy. Therefore, one limitation of this study is that policy support and beliefs about inequality were assessed at a single point in time using a cross-sectional design. However, both theory and prior literature provides support for the argument that beliefs about inequality (which are attributions that reflect core values like individualism, egalitarianism and belief in a just world) are antecedents to policy positions (Bobo \& Kleugal, 1993; Bullock, Williams, \& Limbert 2003; Hunt, 2007; Kleugal, 1990). Ideally, the order of $A$ and $O$ would have been randomized across respondents so that order effects could be estimated and controlled for, but that was
} 


\section{SAMPLE}

The sample was obtained through GfK's KnowledgePanel, which is a randomly selected set of respondents designed to be nationally representative. Detailed information on KnowledgePanel can be found on GfK's website. ${ }^{6}$ Respondents in the panel are selected through random-digit dialing and address-based sampling methods. In this study, we use a sample of employed respondents working for wages/salary (not self-employed) who would be most familiar and potentially most affected by diversity policies. Respondents with missing data on focal variables were removed from the analysis presented here, resulting in the dropping of 10 whites, 24 blacks, and 21 Latinos. The final sample included a total of 1,862 respondents, 755 white, 526 black, and 581 Latino.

\section{MEASURES}

\section{Support for Workplace Policies}

Respondents were asked to provide their level of support for eight different workplace policies: a generic inclusion policy, targeted recruitment, voluntary training, mandatory training, mentorship programs, formalized hiring criteria, creation of a diversity office, and establishing numerical goals. As noted earlier, the phrasing of each workplace policy was randomized to present one of two targets (race or gender) and one of three policy justifications (increase diversity, address discrimination, or none). For example, the six conditions in which respondents were asked their support for targeted recruitment are illustrated below:

\footnotetext{
not the focus of the original study design. However, the design did allow us to test whether the policy support questions may have influenced reported beliefs about inequality by examining if randomly varying policy justifications (to increase diversity/address discrimination/none) affected reported beliefs about inequality. If order effects were present, then beliefs about inequality would differ by policy characteristics. However, this was not the case. As reported in Appendix Table 1, beliefs about the causes of inequality $(A)$ did not differ across policy justifications, suggesting that order effects were non-influential.

${ }^{6}$ https://www.gfk.com/fileadmin/user_upload/dyna_content/US/documents/KnowledgePanel_Methodology.pdf
} 
1) Race-Target, Discrimination Justification: In order to minimize racial discrimination, some companies actively recruit racial minorities to apply for job openings. What is your opinion of this practice?

2) Race-Target, Diversity Justification: In order to create a workplace with more racial diversity, some companies actively recruit racial minorities to apply for job openings. What is your opinion of this practice?

3) Race-Target, No Justification: Some companies actively recruit racial minorities to apply for job openings. What is your opinion of this practice?

4) Gender-Target, Discrimination Justification: In order to minimize gender discrimination, some companies actively recruit women to apply for job openings. What is your opinion of this practice?

5) Gender-Target, Diversity Justification: In order to create a workplace with more gender diversity, some companies actively recruit women to apply for job openings. What is your opinion of this practice?

6) Gender-Target, No Justification: Some companies actively recruit women to apply for job openings. What is your opinion of this practice?

The phrasing of each of the eight policies was similar to the example above, with only the policy (in this case "actively recruit") changing. Respondents rated their level of support toward each of the eight policies on a 1 to 5 scale, ranging from "Strongly Favor" to "Strongly Oppose". To make the interpretation of the scale more intuitive, we recoded these items to range from zero to one so that a score of zero indicates strong opposition, a score of one represents strong support, and a score of .5 indicates that respondents neither favor nor oppose the policy. 


\section{Randomized Policy Characteristics}

Our analytic models below include dummy variables to measure the effects of the various conditions under which the workplace policy questions were asked. We include one dummy variable indicating that the target of the workplace policy was racial minorities (as opposed to women). We also include two dummy variables to indicate whether diversity was given as a justification for the workplace policy or whether there was no justification given (with the justification of addressing discrimination being the reference category).

\section{Beliefs about Gender Inequality/Racial Inequality for African Americans}

The survey also included a series of questions measuring respondents' beliefs about either gender or race inequality. Respondents who answered questions about workplace policies for racial minorities were asked about their beliefs regarding the causes of racial inequality for African Americans. Those answering questions about workplace policies for women were asked about their beliefs regarding the causes of gender inequality. Respondents indicated how important a number of explanations were in explaining inequality for women or African Americans. Specifically, the question was worded:

Here is a list of reasons some people give to explain why, on average, [varied depending on target of policy questions: race-target: African Americans have worse jobs and income than white people; gender target: women have worse jobs and income than men].

Respondents were then prompted to indicate the importance of several factors on a four-point scale ranging from "very important" to "not at all important". Here, we focus on items that were equivalent between the gender and race targets - discrimination, educational opportunity, and training, which were described as reasons for inequality in the following ways:

- Because of workplace discrimination against [African Americans/women] 
- Because most [African Americans/women] don't have the same chance to get the education needed for good jobs.

- Because most [African Americans/women] don't have the training and experience required for good jobs.

Responses were recoded to range from zero to one so that a score of zero indicates that respondents felt that the reason for race/gender inequality was "not at all important" and a score of one means that respondents felt the reason was "very important".

\section{Beliefs about Class Inequality}

In addition to beliefs about race/gender inequality, respondents also indicated their beliefs about class inequality. To measure this item, the survey asked respondents to rate how important certain reasons were to explain "why there are poor people in this country." Here, we focus on four reasons that were found to be particularly influential:

- Being taken advantage of by rich people.

- Failure of society to provide good schools for many Americans.

- Low wages in some businesses and industries.

- Failure of private industry to provide enough good jobs.

Respondents rated these reasons for class inequality on a four-point scale which we recoded to range from zero to one so that a score of zero indicates that respondents felt the reason was "not at all important" and a score of one indicates a feeling that the reason was "very important". Factor analysis revealed that the four items listed above constitute a common underlying variable $($ Cronbach's alpha $=.79)$. Therefore, we took the mean of these four items to create a single item measuring respondents' belief in structural explanations for class inequality. 


\section{Control Variables}

Our analytic models also include a number of control variables that could potentially affect respondents' support for workplace diversity/inclusion policies. To account for social class, we include continuous measures of income and education in each of our models. Because conservatives tend to oppose policies like affirmative action more than liberals (Sniderman and Carmines, 1997), we also include a continuous measure of conservatism. ${ }^{7}$ In other analyses, we included a number of additional control variables such as age and religiosity. Because these variables were not significant in our models and did not affect the overall findings related to our focal predictors, we do not include them in our analysis presented here.

\section{ANALYTIC PLAN}

We begin our discussion of results by using factor analysis to examine whether respondent support for various workplace diversity policies could be combined into a reliable index reflecting general support for diversity policies. After determining that respondent support for different policies can be combined and reflect a single underlying construct, we provide a series of regression models to test the effects of policy target and justification. We then review descriptive statistics for key independent variables. Building from the descriptive trends, we present a series of OLS regression models to examine the relationship between respondents' attributions of inequality and their support for workplace diversity/inclusion policies. In this section of the results, we analyze separately respondent support for gender-based policies and race-based policies. All analyses were performed using Stata statistical software, version 14.2. Throughout our study, we pay attention to the gender and racial differences that emerged in

\footnotetext{
${ }^{7}$ In other analyses, we included additional variables to control for political attitudes such as party affiliation and whether respondents voted for Obama. Because these variables were highly correlated with the measure of political conservatism, and because they add little substantive value to our findings, we do not include them in the results presented here. Substantive findings remain the same when these variables are included in our analytic models.
} 
policy support and beliefs about inequality, testing whether interactions between beliefs about inequality and race/gender significantly predicted policy support. When noteworthy, we mention gender and race interactions (e.g. when trends for white women were exceptionally different from those for black/Latina women and white men). Because these cases were minimal, we focus on variation between, rather than within, gender and race groups. By establishing these trends here, future work may build on this study by delving deeper into variation across detailed race/gender groups.

\section{RESULTS}

\section{Support for Different Types of Diversity Policies}

Figure 2 reports average levels of support across race and gender groups (see Bielby, Krysan, and Herring [2014] for a more thorough analysis of these data). Confirming past results, respondents expressed lower levels of support for policies where gains by one group may be perceived as coming at the expense of another (e.g., targeted recruitment). T-tests of means further revealed significant gender and race differences in levels of support. Men, particularly white men, reported lower levels of support than women for all policies except formal hiring criteria and voluntary training where the difference was non-significant. Significant racial differences existed for all policy items except formal hiring criteria. Blacks reported the highest levels of support, followed by Latinos, with whites having the lowest levels of support. 


\section{Figure 2: Average Levels of Support Across Gender and Race}

For 8 Diversity Policies
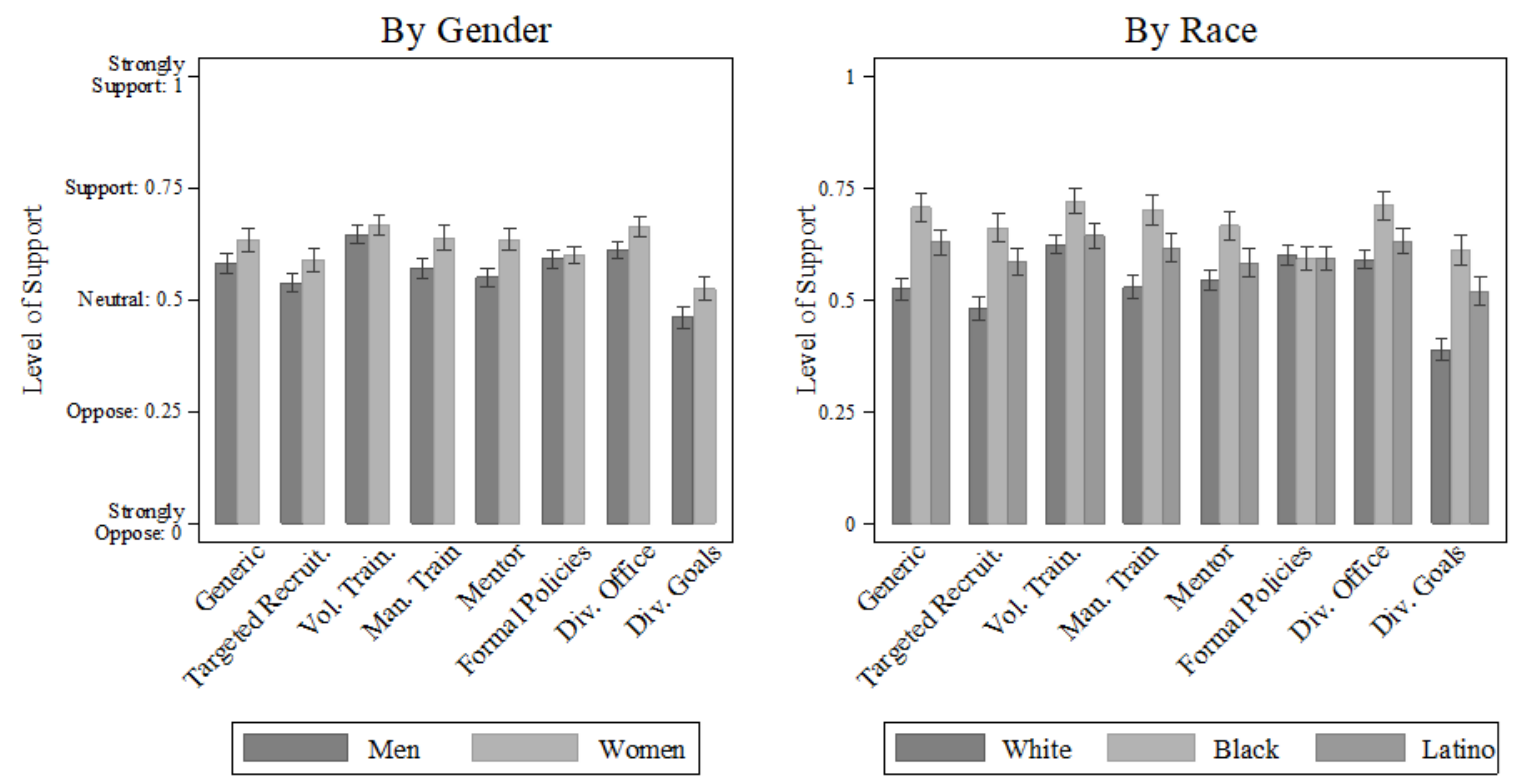

Error bars represent standard errors around point estimates.

Non-overlaping error bars indicate significant between-group difference 
Table 1: Factor Analysis for Diversity Policies by Policy Target and Respondent Race

\begin{tabular}{|c|c|c|c|c|c|c|c|c|}
\hline \multicolumn{9}{|l|}{ Gender-Based Policies } \\
\hline \multirow[b]{2}{*}{ Policy } & \multicolumn{2}{|c|}{ All Respondents } & \multicolumn{2}{|c|}{ Whites } & \multicolumn{2}{|c|}{ Blacks } & \multicolumn{2}{|c|}{ Latinos } \\
\hline & 8 Items & 7 Items & 8 Items & 7 Items & 8 Items & 7 Items & 8 Items & 7 Items \\
\hline Generic & 0.568 & 0.557 & 0.584 & 0.583 & 0.494 & 0.418 & 0.570 & 0.574 \\
\hline Targeted Recruitment & 0.748 & 0.749 & 0.801 & 0.801 & 0.662 & 0.673 & 0.730 & 0.726 \\
\hline Voluntary Training & 0.722 & 0.719 & 0.738 & 0.735 & 0.659 & 0.666 & 0.736 & 0.733 \\
\hline Mandatory Training & 0.671 & 0.673 & 0.710 & 0.710 & 0.648 & 0.656 & 0.612 & 0.608 \\
\hline Mentorship & 0.775 & 0.780 & 0.748 & 0.751 & 0.808 & 0.818 & 0.774 & 0.784 \\
\hline Formal Hiring Policies & 0.399 & & 0.344 & & 0.496 & & 0.463 & \\
\hline Diversity Office & 0.735 & 0.717 & 0.750 & 0.740 & 0.726 & 0.682 & 0.729 & 0.714 \\
\hline Diversity Goals & 0.680 & 0.688 & 0.655 & 0.663 & 0.640 & 0.636 & 0.735 & 0.748 \\
\hline Cronbach's Alpha & 0.855 & 0.865 & 0.849 & 0.863 & 0.855 & 0.856 & 0.845 & 0.851 \\
\hline
\end{tabular}

Race-Based Policies

\begin{tabular}{lcccccccc} 
& \multicolumn{2}{c}{ All Respondents } & \multicolumn{2}{c}{ Whites } & \multicolumn{2}{c}{ Blacks } & \multicolumn{2}{c}{ Latinos } \\
Policy & 8 Items & 7 Items & 8 Items & 7 Items & 8 Items & 7 Items & 8 Items & 7 Items \\
\hline Generic & 0.749 & 0.752 & 0.766 & 0.769 & 0.680 & 0.674 & 0.525 & 0.537 \\
Targeted Recruitment & 0.774 & 0.777 & 0.807 & 0.803 & 0.702 & 0.715 & 0.508 & 0.526 \\
Voluntary Training & 0.636 & 0.635 & 0.621 & 0.619 & 0.721 & 0.724 & 0.454 & 0.476 \\
Mandatory Training & 0.733 & 0.735 & 0.726 & 0.729 & 0.643 & 0.634 & 0.667 & 0.673 \\
Mentorship & 0.674 & 0.666 & 0.682 & 0.674 & 0.661 & 0.650 & 0.622 & 0.620 \\
Formal Hiring Policies & 0.280 & & 0.211 & & 0.534 & & 0.352 & \\
Diversity Office & 0.683 & 0.673 & 0.644 & 0.641 & 0.701 & 0.705 & 0.594 & 0.547 \\
Diversity Goals & 0.711 & 0.716 & 0.628 & 0.632 & 0.567 & 0.565 & 0.704 & 0.697 \\
\hline Cronbach's Alpha & 0.873 & 0.888 & 0.861 & 0.881 & 0.857 & 0.856 & 0.828 & 0.837 \\
\hline
\end{tabular}

We used exploratory factor analysis and scale reliability analysis to examine whether support for the different diversity policies can be combined into a reliable index. Even though mean levels of support vary from policy to policy, if respondents who are supportive of one policy tend to be supportive of others, then general policy support may constitute a single construct. Table 1 provides the factor loadings and Cronbach's Alphas for each of the eight policy items by race group and target condition. When we included all eight items in the factor analysis, factor loadings generally ranged between .6 and .8 across all policies except formal 
hiring criteria, which had much lower factor loading ranging between .21 and .54 . This suggests

there is something unique about this particular policy that causes it to depart from the more regular response patterns shown in the other questions. ${ }^{8}$ When we removed formal hiring policies from the factor analysis, factor loadings for the remaining seven policy questions continued to be high, and the Cronbach's Alpha was improved relative to the eight-item index. These results indicate that respondent support for diversity policies (except formal hiring criteria) reflect a single underlying construct.

We combined the seven measures (excluding formal hiring criteria) into an index by averaging support scores across these policies. ${ }^{9}$ This resulting construct ranges from zero (strong opposition to diversity policies) to one (strong support), with a score of .5 indicating respondents neither oppose nor support diversity policies.

\section{Policy Characteristics}

Figure 3 illustrates mean levels of support for workplace policies by policy target across gender and race groups. ${ }^{10}$ For policies targeted towards women, blacks show significantly higher levels of support than whites $(\mathrm{p}<.001)$ and Latinos $(\mathrm{p}<.01)$. The difference between whites and Latinos was not significant. In policies targeted towards racial minorities, racial differences are

\footnotetext{
${ }^{8}$ Despite the fact that the factor loadings for the policy of formal hiring criteria were lower than the other policies, the Cronbach's Alpha remains sufficiently high even when including this measure. The results of this study are substantively the same when including all eight policies in the single construct.

${ }^{9}$ Previous research (Bielby, Krysan, Herring, 2014) using these data to examine the eight policies separately found that whites were less supportive of targeted recruitment and numerical goals than the remaining initiatives. We chose to measure policy support as a single factor because a two-factor model did not load as consistently across race groups as compared to a single factor model constructed with all seven policies. Nonetheless, all results here are replicated, and substantive findings remain the same, when examining predictors of support for each specific diversity policy and using ordered logistic regression models that account for the ordinal response options of each policy attitude item. One exception was in respondents' support for formal hiring policies, where no race or gender differences were observed indicating that this policy is unique. This particular question measured a different construct than the other policy items.

${ }^{10}$ Throughout this manuscript, we use t-tests in comparing group mean differences and Wald Tests when comparing differences in coefficients between OLS models.
} 
highly significant between each group ( $\mathrm{p}<.001)$, with blacks showing the highest levels of support, followed by Latinos, while whites reported the lowest support for workplace policies.

Figure 3 also shows that women express more support than men for workplace policies aimed at supporting women $(\mathrm{p}<.001)$ and racial minorities $(\mathrm{p}<.05)$, although, these gender differences were most pronounced for whites. Examining levels of support across policy target, only white respondents (both women and men) were more likely to support gender-based policies than race-based policies $(\mathrm{p}<.001)$.

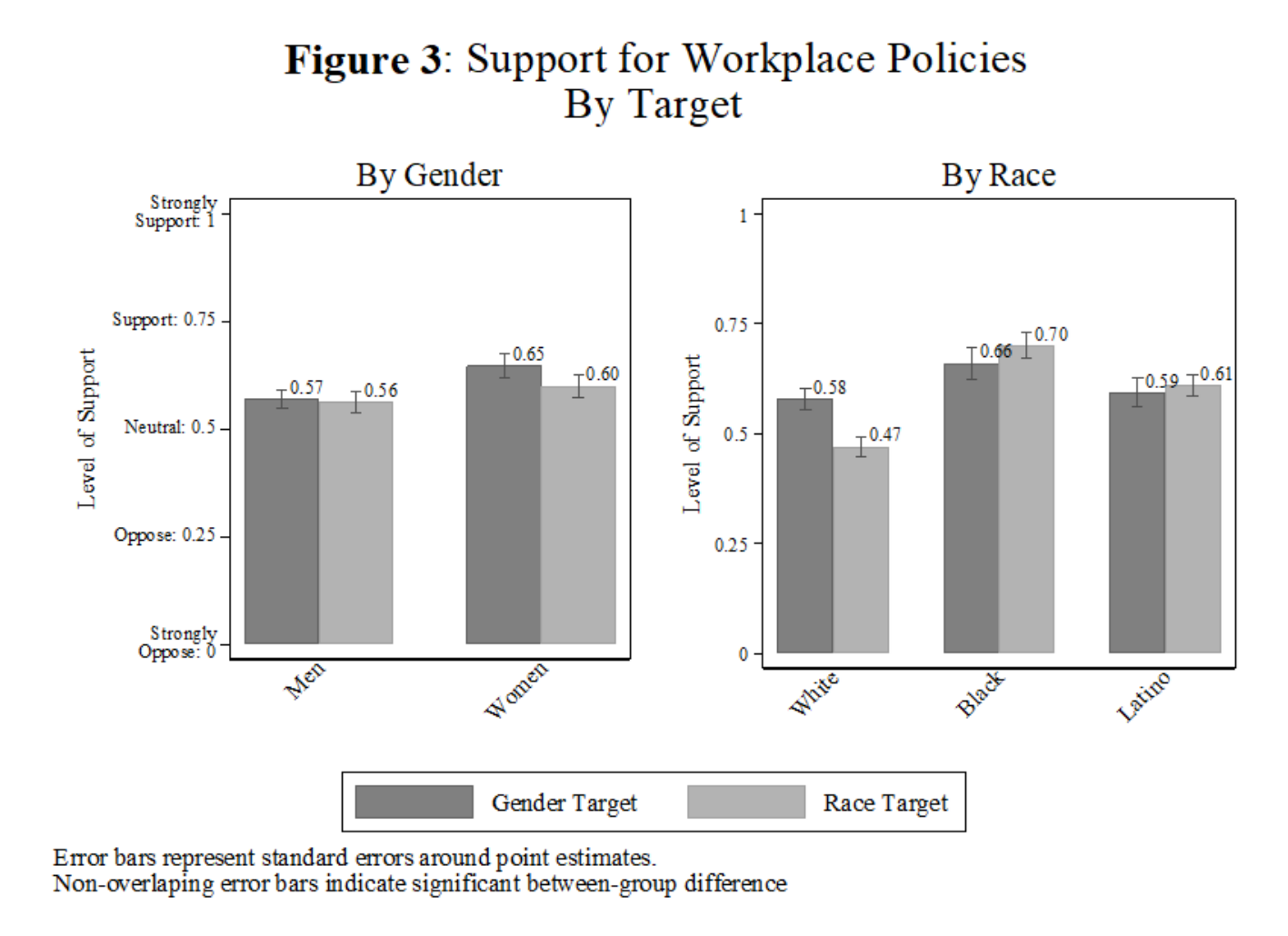

The results in Figure 3 also suggest that the target of workplace policies affects only whites', and not blacks' or Latinos' support of diversity/inclusion efforts. To determine whether these results remain when controlling for several potentially confounding variables, Table 2 provides the results of three OLS regression models examining the effect of policy condition on 
support for workplace policies. These regression models also allow us to test whether policy justification - the other manipulated variable in the study - influences levels of support.

Consistent with descriptive trends, Model 1 shows that blacks report higher levels of support for workplace policies than Latinos, and Latinos report higher levels of support than whites $(\mathrm{p}<.001)$. Women are also more supportive of diversity policies than men $(\mathrm{p}<.001)$. White respondents who were asked about workplace policies targeting racial minorities reported lower levels of support than respondents who were asked about workplace policies for women $(\mathrm{p}<.01)$. Black respondents had slightly higher support for race-based policies $(\mathrm{p}<.01)$ and Latinos reported similar levels of support for policies aimed at women or racial minorities. Table 2 also reveals that workplace policies receive less support when justified to increase diversity as compared to when justified to address discrimination $(\mathrm{p}<.01)$. 
Table 2: OLS Models Testing Effects of Randomized Policy Characteristics on Support for Workplace Policies

\begin{tabular}{|c|c|c|c|}
\hline & Target & $\begin{array}{c}\text { Target } \\
\text { Interactions }\end{array}$ & $\begin{array}{l}\text { Justification } \\
\text { Interactions }\end{array}$ \\
\hline \multicolumn{4}{|l|}{ Sex (Male) } \\
\hline Female & $\begin{array}{l}0.048 * * * \\
(0.012)\end{array}$ & $\begin{array}{l}0.072 * * * \\
(0.017)\end{array}$ & $\begin{array}{l}0.034 \\
(0.019)\end{array}$ \\
\hline \multicolumn{4}{|l|}{ Race (White) } \\
\hline Black & $\begin{array}{l}0.152 * * * \\
(0.015)\end{array}$ & $\begin{array}{l}0.073 * * * \\
(0.021)\end{array}$ & $\begin{array}{l}0.145^{* * *} \\
(0.023)\end{array}$ \\
\hline Latino & $\begin{array}{l}0.082 * * * \\
(0.014)\end{array}$ & $\begin{array}{l}0.026 \\
(0.020)\end{array}$ & $\begin{array}{l}0.086^{* * *} \\
(0.024)\end{array}$ \\
\hline \multicolumn{4}{|l|}{ Target (Gender) } \\
\hline Race Target & $\begin{array}{l}-0.031 * * \\
(0.012)\end{array}$ & $\begin{array}{l}-0.083 * * * \\
(0.018)\end{array}$ & $\begin{array}{l}-0.031 * * \\
(0.011)\end{array}$ \\
\hline Target*Black & & $\begin{array}{l}0.153 * * * \\
(0.029)\end{array}$ & \\
\hline Race Target*Latino & & $\begin{array}{l}0.113 * * * \\
(0.027)\end{array}$ & \\
\hline \multicolumn{2}{|l|}{ Race Target*Female } & $\begin{array}{l}-0.051 * \\
(0.023)\end{array}$ & \\
\hline \multicolumn{4}{|c|}{ Justification for Policy (Discrimination) } \\
\hline Diversity & $\begin{array}{l}-0.036^{*} \\
(0.014)\end{array}$ & $\begin{array}{l}-0.038 * * \\
(0.013)\end{array}$ & $\begin{array}{l}-0.036 \\
(0.023)\end{array}$ \\
\hline Diversity*Black & & & $\begin{array}{l}-0.006 \\
(0.034)\end{array}$ \\
\hline Diversity*Latino & & & $\begin{array}{l}-0.012 \\
(0.032)\end{array}$ \\
\hline Diversity*Female & & & $\begin{array}{l}0.014 \\
(0.028)\end{array}$ \\
\hline None & $\begin{array}{l}-0.018 \\
(0.014)\end{array}$ & $\begin{array}{l}-0.016 \\
(0.014)\end{array}$ & $\begin{array}{l}-0.037 \\
(0.022)\end{array}$ \\
\hline None*Black & & & $\begin{array}{l}0.025 \\
(0.035)\end{array}$ \\
\hline None*Latino & & & $\begin{array}{l}-0.002 \\
(0.034)\end{array}$ \\
\hline None*Female & & & $\begin{array}{l}0.029 \\
(0.029)\end{array}$ \\
\hline \multicolumn{4}{|l|}{ Controls } \\
\hline Income & $\begin{array}{l}0.001 \\
(0.002)\end{array}$ & $\begin{array}{l}0.000 \\
(0.002)\end{array}$ & $\begin{array}{l}0.001 \\
(0.002)\end{array}$ \\
\hline
\end{tabular}




\begin{tabular}{clll} 
Education & 0.005 & 0.005 & 0.005 \\
& $(0.004)$ & $(0.003)$ & $(0.004)$ \\
Political Conserv. & $-0.167 * * *$ & $-0.166^{* * *}$ & $-0.168 * * *$ \\
& $(0.028)$ & $(0.027)$ & $(0.027)$ \\
Constant & $0.556^{* * *}$ & $0.584 * * *$ & $0.564 * * *$ \\
& $(0.045)$ & $(0.044)$ & $(0.046)$ \\
N & 1862 & 1862 & 1862 \\
R-sq & 0.191 & 0.225 & 0.193 \\
\hline
\end{tabular}

Standard errors in parentheses

$* \mathrm{p}<0.05 ; * * \mathrm{p}<0.01 ; * * * \mathrm{p}<0.001$

\section{Beliefs about Inequality}

Figure 4 reports differences across race, gender, and target conditions in respondents' beliefs about inequality. Descriptive information for all variables used in our analyses can be found in the Appendix Table 2. All graphs but two in Figure 4 are split across target conditions, since these questions were either asked about gender inequality or racial inequality for African Americans. Graphs reporting beliefs about class inequality are not split by target condition because the wording of this question did not vary across respondents. In general, blacks reported the highest levels of support for all explanations of inequality, followed by Latinos, with whites showing the lowest levels of support. These racial differences were highest for discrimination as a source of inequality, where whites showed particularly low support of discrimination when framed as a cause of racial inequality. Examining support for policies directed towards racial inequality versus gender inequality showed that respondents generally reported greater support for educational opportunity and training as sources of racial, rather than gender, inequality. This trend was most pronounced for black respondents. Both whites and Latinos showed greater endorsement of discrimination as an explanation of gender inequality than racial inequality. Finally, blacks reported the highest endorsement of structural reasons for inequality, followed by Latinos, with whites showing the lowest beliefs in structural determinants of class inequality. 


\section{Figure 4: Beliefs in Sources of Inequality}

By Gender
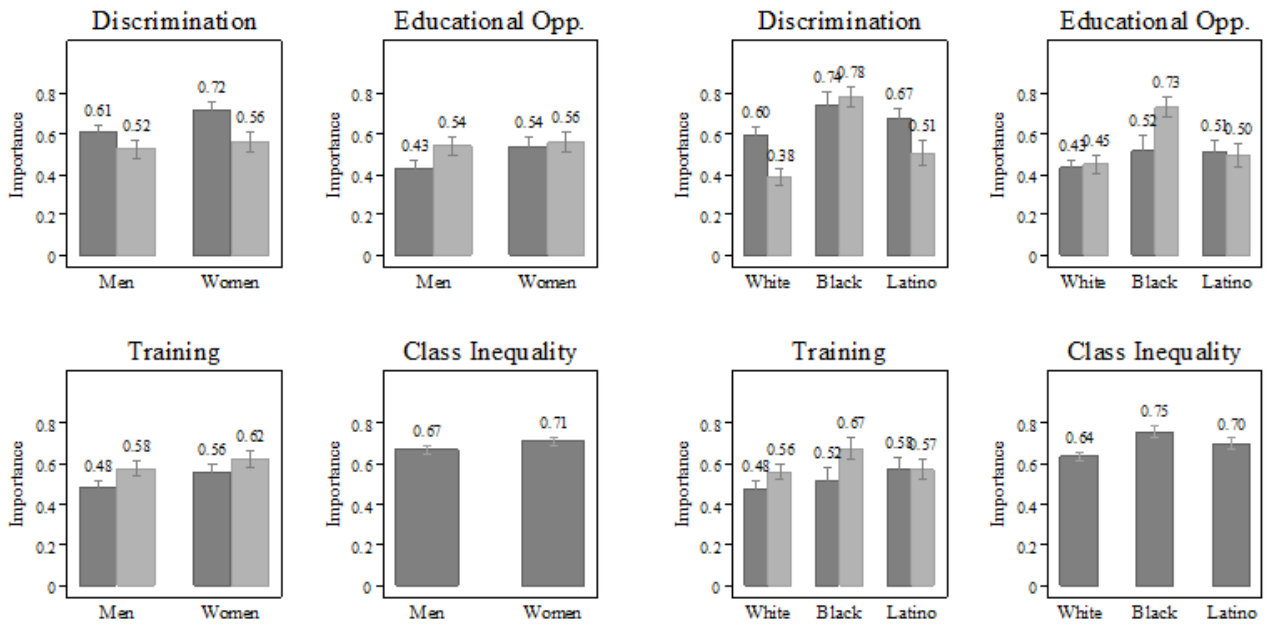

Race Target

Error bars represent standard errors around point estimates.

Non-overlaping error bars indicate significant between-group difference

Beliefs about the sources of inequality by also varied by respondent gender, but only for

explanations of gender inequality and not racial inequality. Women reported greater endorsement of each of the three attributions of gender inequality than men. Analysis not presented here showed that these gender differences were most pronounced for whites. Women were also more likely to agree with structural reasons for class inequality than men $(\mathrm{p}<.05)$.

\section{Support for Gender-Based Workplace Policies}

Table 3 presents the results of OLS regressions predicting support for workplace policies designed to improve the representation of women. The attributions of inequality questions for these respondents (all except for those relating to class inequality) were also framed in terms of gender, rather than race, inequality. The first model in Table 3 includes only control variables. In this base model, women showed higher levels of support for gender-based workplace policies than men $(\mathrm{p}<.001)$ and blacks supported these policies more than whites $(\mathrm{p}<.001)$. Latinos did 
not differ from whites or blacks. Policy justification was unrelated to support for gender-based workplace policies, with respondents showing similar levels of policy support when policies were framed as being needed to address discrimination, improve diversity, or when no justification was given. Income and education were unrelated to policy support, while political conservatism predicted lower levels of support for gender-based workplace policies. The effects of these variables remained consistent across subsequent models in Table 3.

The next three models examine whether respondents' beliefs in various explanations for gender inequality predict their support for gender-based workplace policies, while an additional model tests whether beliefs about structural causes for class inequality predicted policy support. All inequality beliefs are highly associated with policy support $(\mathrm{p}<.001)$, but the size of the coefficients range considerably. ${ }^{11}$ Respondents' belief in training as a source of gender inequality had the smallest effects, followed by educational opportunity. The coefficient for respondent belief in discrimination as a source of inequality was much larger than the coefficients for training beliefs and educational opportunity. The largest effects, however, were observed for respondents' belief in structural reasons for class inequality. Those endorsing structural causes of class inequality were more likely to support gender-based workplace policies.

Despite respondents' belief in structural causes of class inequality having the largest coefficient, it did not account for the most substantial share of the observed gender and race differences found in the base model. Instead, discrimination beliefs mediated the largest portion of gender and race differences in policy support, accounting for 39\% of the gender difference and $46 \%$ of the black-white difference (Sobel-Goodman tests $\mathrm{p}<.001$ ). This finding indicates that

\footnotetext{
${ }^{11}$ Coefficients for these variables are directly comparable because each is measured on a $0-1$ scale.
} 
women and blacks have higher levels of policy support than men and non-blacks because they more strongly believe that discrimination is a cause of gender inequality. 
Table 3: OLS Models Predicting Support for Workplace Policies to Support Women

\begin{tabular}{|c|c|c|c|c|c|c|c|}
\hline & Base & Discrim. & $\begin{array}{l}\text { Educ. } \\
\text { Opp. }\end{array}$ & Training & Class Ineq. & Full & Interactions \\
\hline \multicolumn{8}{|l|}{ Sex (Male) } \\
\hline Female & $\begin{array}{l}0.071 * * * \\
(0.017)\end{array}$ & $\begin{array}{l}0.043 * * \\
(0.015)\end{array}$ & $\begin{array}{l}0.051 * * \\
(0.016)\end{array}$ & $\begin{array}{l}0.062 * * * \\
(0.017)\end{array}$ & $\begin{array}{l}0.060 * * * \\
(0.015)\end{array}$ & $\begin{array}{l}0.040 * * \\
(0.014)\end{array}$ & $\begin{array}{l}0.020 \\
(0.041)\end{array}$ \\
\hline \multicolumn{8}{|l|}{ Race (White) } \\
\hline Black & $\begin{array}{l}0.072 * * * \\
(0.021)\end{array}$ & $\begin{array}{l}0.039 * \\
(0.019)\end{array}$ & $\begin{array}{l}0.062 * * * \\
(0.019)\end{array}$ & $\begin{array}{l}0.069 * * * \\
(0.020)\end{array}$ & $\begin{array}{l}0.055 * * \\
(0.018)\end{array}$ & $\begin{array}{l}0.037 * \\
(0.018)\end{array}$ & $\begin{array}{l}0.087 \\
(0.048)\end{array}$ \\
\hline Latino & $\begin{array}{l}0.028 \\
(0.020)\end{array}$ & $\begin{array}{l}0.006 \\
(0.017)\end{array}$ & $\begin{array}{l}0.015 \\
(0.019)\end{array}$ & $\begin{array}{l}0.019 \\
(0.020)\end{array}$ & $\begin{array}{l}0.019 \\
(0.017)\end{array}$ & $\begin{array}{l}0.005 \\
(0.016)\end{array}$ & $\begin{array}{l}-0.045 \\
(0.041)\end{array}$ \\
\hline \multicolumn{8}{|c|}{ Beliefs About Gender Inequality } \\
\hline \multicolumn{2}{|l|}{ Discrimination } & $\begin{array}{l}0.280 * * * \\
(0.030)\end{array}$ & & & & $\begin{array}{l}0.182 * * * \\
(0.031)\end{array}$ & $\begin{array}{l}0.165 * * * \\
(0.040)\end{array}$ \\
\hline Opportunity & & & $\begin{array}{l}0.182 * * * \\
(0.026)\end{array}$ & & & $\begin{array}{l}0.070^{*} \\
(0.030)\end{array}$ & $\begin{array}{l}0.072 * \\
(0.029)\end{array}$ \\
\hline Training & & & & $\begin{array}{l}0.113 * * * \\
(0.027)\end{array}$ & & $\begin{array}{l}-0.022 \\
(0.029)\end{array}$ & $\begin{array}{l}-0.021 \\
(0.028)\end{array}$ \\
\hline \multicolumn{4}{|c|}{ Beliefs About Structural Reason for Class Inequality } & & $\begin{array}{l}0.325 * * * \\
(0.037)\end{array}$ & $\begin{array}{l}0.202 * * * \\
(0.034)\end{array}$ & $\begin{array}{l}0.200 * * * \\
(0.034)\end{array}$ \\
\hline \multicolumn{8}{|l|}{ Race Interactions } \\
\hline \multicolumn{4}{|c|}{ Blacks*Belief in Discrim. } & & & & $\begin{array}{l}-0.066 \\
(0.063)\end{array}$ \\
\hline \multicolumn{4}{|c|}{ Latino*Belief in Discrim } & & & & $\begin{array}{l}0.075 \\
(0.060)\end{array}$ \\
\hline \multicolumn{8}{|l|}{ Gender Interactions } \\
\hline \multicolumn{4}{|c|}{ Female*Belief in Discrim } & & & & $\begin{array}{l}0.031 \\
(0.055)\end{array}$ \\
\hline \multicolumn{8}{|c|}{ Justification for Policy (Discrimination) } \\
\hline Diversity & $\begin{array}{l}-0.018 \\
(0.019)\end{array}$ & $\begin{array}{l}-0.025 \\
(0.017)\end{array}$ & $\begin{array}{l}-0.020 \\
(0.018)\end{array}$ & $\begin{array}{l}-0.023 \\
(0.019)\end{array}$ & $\begin{array}{l}-0.009 \\
(0.016)\end{array}$ & $\begin{array}{l}-0.017 \\
(0.016)\end{array}$ & $\begin{array}{l}-0.022 \\
(0.015)\end{array}$ \\
\hline None & $\begin{array}{l}0.012 \\
(0.019)\end{array}$ & $\begin{array}{l}0.001 \\
(0.016)\end{array}$ & $\begin{array}{l}0.003 \\
(0.017)\end{array}$ & $\begin{array}{l}0.010 \\
(0.019)\end{array}$ & $\begin{array}{l}0.008 \\
(0.017)\end{array}$ & $\begin{array}{l}-0.001 \\
(0.015)\end{array}$ & $\begin{array}{l}-0.002 \\
(0.015)\end{array}$ \\
\hline \multicolumn{8}{|l|}{ Controls } \\
\hline Income & $\begin{array}{l}0.002 \\
(0.003)\end{array}$ & $\begin{array}{l}0.003 \\
(0.002)\end{array}$ & $\begin{array}{l}0.003 \\
(0.002)\end{array}$ & $\begin{array}{l}0.002 \\
(0.003)\end{array}$ & $\begin{array}{l}0.003 \\
(0.002)\end{array}$ & $\begin{array}{l}0.004 \\
(0.002)\end{array}$ & $\begin{array}{l}0.004 \\
(0.002)\end{array}$ \\
\hline Education & $\begin{array}{l}0.005 \\
(0.005)\end{array}$ & $\begin{array}{l}0.008 \\
(0.004)\end{array}$ & $\begin{array}{l}0.008 \\
(0.004)\end{array}$ & $\begin{array}{l}0.008 \\
(0.005)\end{array}$ & $\begin{array}{l}0.009 * \\
(0.004)\end{array}$ & $\begin{array}{l}0.010^{*} \\
(0.004)\end{array}$ & $\begin{array}{l}0.010 * \\
(0.004)\end{array}$ \\
\hline $\begin{array}{l}\text { Political } \\
\text { Conserv. }\end{array}$ & $\begin{array}{l}-0.241 * * * \\
(0.038)\end{array}$ & $\begin{array}{l}-0.158 * * * \\
(0.032)\end{array}$ & $\begin{array}{l}-0.228 * * * \\
(0.035)\end{array}$ & $\begin{array}{l}-0.248^{* * *} \\
(0.037)\end{array}$ & $\begin{array}{l}-0.183 * * * \\
(0.032)\end{array}$ & $\begin{array}{l}-0.145^{* * * *} \\
(0.030)\end{array}$ & $\begin{array}{l}-0.145^{* * *} \\
(0.031)\end{array}$ \\
\hline
\end{tabular}




\begin{tabular}{clllllll} 
Constant & $0.578 * * *$ & $0.356 * * *$ & $0.469 * * *$ & $0.500 * * *$ & $0.282 * * *$ & $0.223 * * *$ & $0.231 * * *$ \\
& $(0.064)$ & $(0.061)$ & $(0.065)$ & $(0.064)$ & $(0.065)$ & $(0.061)$ & $(0.065)$ \\
$\mathrm{N}$ & 929 & 929 & 929 & 929 & 929 & 929 & 929 \\
$\mathrm{R}-\mathrm{sq}$ & 0.186 & 0.364 & 0.286 & 0.223 & 0.334 & 0.425 & 0.432 \\
\hline
\end{tabular}

Standard errors in parentheses

$* \mathrm{p}<0.05 ; * * \mathrm{p}<0.01 ; * * * \mathrm{p}<0.001$

Including all focal variables in the same model (full model), provides further support for the centrality of discrimination beliefs and class attitudes in policy support. In this model, discrimination beliefs and attitudes about class inequality have the strongest effect. Additionally, beliefs about discrimination was the primary mediator of the observed gender and race differences. The final model in Table 3 used interaction terms to test whether the effect of respondents' belief in discrimination differ across race and gender groups. Results indicate that this variable has the same effect for women and men, as well as whites, blacks, and Latinos.

\section{Support for Race-Based Workplace Policies}

Table 4 reports the results of models predicting support for workplace policies designed to improve racial diversity. The equations are the same as in the previous table, but they include only respondents asked about policies aimed to improve the representation of racial minorities and attributions of inequality for African Americans.

Model 1 reveals significant racial differences in support for workplace policies designed to improve racial diversity. Blacks report the highest levels of support, followed by Latinos, with whites espousing the least support. Differences between each race group were highly significant $(\mathrm{p}<.001)$. There were no significant gender differences observed in support for race-based workplace policies. Among the covariates, income and education were unrelated to policy support, while political conservatism had a negative association, such that conservative attitudes 
predicted lower levels of support for race-based workplace policies $(\mathrm{p}<.05)$. We also find that respondents' showed less support for workplace policies when they were framed as needed to improve diversity $(\mathrm{p}<.01)$ or when no justification was given $(\mathrm{p}<.05)$ compared to when the policy was justified to address discrimination. These findings indicate that the framing of workplace policies - whether justified as needed for discrimination, diversity, or not justified at all, is more influential for race-based policies than gender-based policies. Among race-based workplace policies, the highest levels of support are reported when policies are framed as being necessary to decrease discrimination. A justification to improve diversity received just as much support as if no justification was given.

The next three models in Table 4 test whether respondents' beliefs about inequality for African Americans predicts policy-support, while an additional model explores the relationship between beliefs about class inequality and policy support. The results are consistent with key findings from gender-based policies. All inequality belief variables are significant predictors of race-based policy support $(\mathrm{p}<.001)$. The largest effects are observed for respondents' support of structural reasons for class inequality, followed by respondents' belief that discrimination causes racial inequality. The coefficients for educational opportunity and training were substantially lower. Across these models, respondents' beliefs about discrimination mediated the largest share of the observed racial differences in the base model, accounting for $40 \%$ of the black/white difference, $18 \%$ of the Latino/white difference, and $73 \%$ of the black/Latino difference. These mediation effects are highly significant $(\mathrm{p}<.001)$ and substantially larger than the mediation observed with the inclusion of the other inequality beliefs, including the variable measuring respondents' belief about class inequality. We also found that the inclusion of discrimination and educational opportunity as explanations for racial inequality, as well as respondents' belief in 
structural reasons for class inequality, fully mediated differences in support for policies justified to address discrimination and those without any justification at all. Across all models, however, workplace policies to improve diversity were consistently supported less than those framed to address discrimination. 
Table 4: OLS Models Predicting Support for Workplace Policies to Support Racial Minorities

\begin{tabular}{|c|c|c|c|c|c|c|c|}
\hline & Base & Discrim. & $\begin{array}{l}\text { Educ. } \\
\text { Opp. }\end{array}$ & Training & $\begin{array}{l}\text { Class } \\
\text { Ineq. }\end{array}$ & Full & Interactions \\
\hline \multicolumn{8}{|l|}{ Sex (Male) } \\
\hline Female & $\begin{array}{l}0.022 \\
(0.016)\end{array}$ & $\begin{array}{l}0.022 \\
(0.015)\end{array}$ & $\begin{array}{l}0.023 \\
(0.015)\end{array}$ & $\begin{array}{l}0.019 \\
(0.015)\end{array}$ & $\begin{array}{l}0.017 \\
(0.015)\end{array}$ & $\begin{array}{l}0.019 \\
(0.014)\end{array}$ & $\begin{array}{l}0.021 \\
(0.025)\end{array}$ \\
\hline \multicolumn{8}{|l|}{ Race (White) } \\
\hline Black & $\begin{array}{l}0.227 * * * \\
(0.020)\end{array}$ & $\begin{array}{l}0.138 * * * \\
(0.021)\end{array}$ & $\begin{array}{l}0.184 * * * \\
(0.023)\end{array}$ & $\begin{array}{l}0.218 * * * \\
(0.020)\end{array}$ & $\begin{array}{l}0.191 * * * \\
(0.023)\end{array}$ & $\begin{array}{l}0.130 * * * \\
(0.022)\end{array}$ & $\begin{array}{l}0.162 * * * \\
(0.047)\end{array}$ \\
\hline Latino & $\begin{array}{l}0.139 * * * \\
(0.018)\end{array}$ & $\begin{array}{l}0.114 * * * \\
(0.018)\end{array}$ & $\begin{array}{l}0.132 * * * \\
(0.018)\end{array}$ & $\begin{array}{l}0.137 * * * \\
(0.018)\end{array}$ & $\begin{array}{l}0.122 * * * \\
(0.018)\end{array}$ & $\begin{array}{l}0.108 * * * \\
(0.017)\end{array}$ & $\begin{array}{l}0.185^{* * * *} \\
(0.029)\end{array}$ \\
\hline \multicolumn{8}{|c|}{ Beliefs About Racial Inequality } \\
\hline Discrimination & & $\begin{array}{l}0.231 * * * \\
(0.026)\end{array}$ & & & & $\begin{array}{l}0.181 * * * \\
(0.034)\end{array}$ & $\begin{array}{l}0.261 * * * \\
(0.051)\end{array}$ \\
\hline Opportunity & & & $\begin{array}{l}0.154 * * * \\
(0.027)\end{array}$ & & & $\begin{array}{l}0.019 \\
(0.036)\end{array}$ & $\begin{array}{l}0.021 \\
(0.035)\end{array}$ \\
\hline Training & & & & $\begin{array}{l}0.086 * * * \\
(0.024)\end{array}$ & & $\begin{array}{l}-0.020 \\
(0.030)\end{array}$ & $\begin{array}{l}-0.020 \\
(0.029)\end{array}$ \\
\hline \multicolumn{4}{|c|}{ Beliefs About Structural Reason for Class Inequality } & & $\begin{array}{l}0.272 * * * \\
(0.045)\end{array}$ & $\begin{array}{l}0.174 * * * \\
(0.046)\end{array}$ & $\begin{array}{l}0.173 * * * \\
(0.044)\end{array}$ \\
\hline \multicolumn{8}{|l|}{ Race Interactions } \\
\hline \multicolumn{4}{|c|}{ Blacks*Belief in Discrim. } & & & & $\begin{array}{l}-0.080 \\
(0.065)\end{array}$ \\
\hline \multicolumn{4}{|c|}{ Latino*Belief in Discrim } & & & & $\begin{array}{l}-0.171 * * \\
(0.054)\end{array}$ \\
\hline \multicolumn{8}{|l|}{ Gender Interactions } \\
\hline \multicolumn{4}{|c|}{ Female*Belief in Discrim } & & & & $\begin{array}{l}-0.008 \\
(0.042)\end{array}$ \\
\hline \multicolumn{8}{|c|}{ Justification for Policy (Discrimination) } \\
\hline Diversity & $\begin{array}{l}-0.052 * * \\
(0.019)\end{array}$ & $\begin{array}{l}-0.048 * * \\
(0.017)\end{array}$ & $\begin{array}{l}-0.041 * \\
(0.018)\end{array}$ & $\begin{array}{l}-0.048 * * \\
(0.018)\end{array}$ & $\begin{array}{l}-0.048 * * \\
(0.017)\end{array}$ & $\begin{array}{l}-0.046^{* *} \\
(0.017)\end{array}$ & $\begin{array}{l}-0.045^{* *} \\
(0.016)\end{array}$ \\
\hline None & $\begin{array}{l}-0.040 * \\
(0.019)\end{array}$ & $\begin{array}{l}-0.030 \\
(0.017)\end{array}$ & $\begin{array}{l}-0.028 \\
(0.018)\end{array}$ & $\begin{array}{l}-0.040 * \\
(0.019)\end{array}$ & $\begin{array}{l}-0.025 \\
(0.018)\end{array}$ & $\begin{array}{l}-0.021 \\
(0.016)\end{array}$ & $\begin{array}{l}-0.022 \\
(0.016)\end{array}$ \\
\hline \multicolumn{8}{|l|}{ Controls } \\
\hline Income & $\begin{array}{l}-0.001 \\
(0.002)\end{array}$ & $\begin{array}{l}0.001 \\
(0.002)\end{array}$ & $\begin{array}{l}-0.001 \\
(0.002)\end{array}$ & $\begin{array}{l}-0.002 \\
(0.002)\end{array}$ & $\begin{array}{l}-0.000 \\
(0.002)\end{array}$ & $\begin{array}{l}0.001 \\
(0.002)\end{array}$ & $\begin{array}{l}0.001 \\
(0.002)\end{array}$ \\
\hline Education & $\begin{array}{l}0.005 \\
(0.005)\end{array}$ & $\begin{array}{l}0.003 \\
(0.004)\end{array}$ & $\begin{array}{l}0.003 \\
(0.005)\end{array}$ & $\begin{array}{l}0.004 \\
(0.005)\end{array}$ & $\begin{array}{l}0.006 \\
(0.004)\end{array}$ & $\begin{array}{l}0.004 \\
(0.004)\end{array}$ & $\begin{array}{l}0.004 \\
(0.004)\end{array}$ \\
\hline $\begin{array}{l}\text { Political } \\
\text { Conserv. }\end{array}$ & $\begin{array}{l}-0.091 * \\
(0.035)\end{array}$ & $\begin{array}{l}-0.061 \\
(0.032)\end{array}$ & $\begin{array}{l}-0.049 \\
(0.034)\end{array}$ & $\begin{array}{l}-0.083 * \\
(0.035)\end{array}$ & $\begin{array}{l}-0.040 \\
(0.033)\end{array}$ & $\begin{array}{l}-0.032 \\
(0.029)\end{array}$ & $\begin{array}{l}-0.018 \\
(0.031)\end{array}$ \\
\hline
\end{tabular}




\begin{tabular}{clllllll} 
Constant & $0.500^{* * *}$ & $0.385^{* * *}$ & $0.426 * * *$ & $0.456^{* * *}$ & $0.271 * * *$ & $0.264 * * *$ & $0.230^{* * *}$ \\
& $(0.057)$ & $(0.047)$ & $(0.050)$ & $(0.053)$ & $(0.051)$ & $(0.051)$ & $(0.051)$ \\
$\mathrm{N}$ & 933 & 933 & 933 & 933 & 933 & 933 & 933 \\
$\mathrm{R}-\mathrm{sq}$ & 0.276 & 0.398 & 0.338 & 0.294 & 0.357 & 0.428 & 0.440 \\
\hline
\end{tabular}

Standard errors in parentheses

$* \mathrm{p}<0.05 ; * * \mathrm{p}<0.01 ; * * * \mathrm{p}<0.001$

In the full model, we included all variables measuring respondents' attributions for racial inequality and their endorsement of structural reasons for class inequality. We found evidence for the centrality of respondents' beliefs in discrimination - those with higher levels of this belief were more likely to support race-based workplace policies $(\mathrm{p}<.001)$. Not only was the coefficient for this variable larger than others in the model, but it appears to have had the strongest effect on mediating the observed racial differences in policy support, as the coefficients estimating these effects are approximately the same size as they were in the second model when beliefs about discrimination was the only focal independent variable included. Respondent beliefs about class inequality remained highly predictive of policy support in the full model $(\mathrm{p}<.001)$, although the size of the coefficient reduced substantially.

In the last model in Table 4, we test whether respondents' belief in discrimination as a source of inequality has the same effect across race and gender groups. Endorsement of discrimination as a source of inequality significantly predicts support for workplace policies across both gender and race. However, the effects are only marginally significant for Latinos while being highly significant for whites and blacks $(\mathrm{p}<.01)$. We believe that the reason for this is that the question measuring respondents' beliefs about discrimination referred explicitly to African Americans and did not mention Latinos ("discrimination against African Americans"), whereas the questions about diversity policies more broadly referenced "racial diversity". 
Therefore, Latino respondents likely saw the attribution questions as not applying to themselves or their group whereas they perceived the racial diversity policy questions as including Latinos.

In sum, the results from Tables 3 and 4 point to the importance of respondents' beliefs about discrimination in support for diversity/inclusion policies. Beliefs about discrimination was a powerful predictor of support for diversity policies. Furthermore, gender and race differences in policy support were largely explained by differences between these groups in levels of endorsement that discrimination causes inequality.

\section{Summary of Results}

Table 5 summarizes the key findings for each of our three research questions. In general, our study reveals significant gender and race differences in support for diversity policies. These findings are mirrored by gender/race variation in beliefs about whether discrimination causes inequality. Consistent with these trends, we found that differences between gender and race groups in beliefs about discrimination, with women and non-whites being more likely to believe discrimination causes gender/racial inequality, are a major reason why there are race/gender differences in support for diversity policies. One surprising finding was that respondents' beliefs about class inequality was a significant predictor of policy support, while being unrelated to observed gender and racial differences in policy support. 


\section{Table 5: Summary of Results}

Research How are individuals' race and gender associated with their support for

Question 1: $\quad$ workplace diversity policies? Latinos, with whites showing the lowest levels of support. Across gender, women are more supportive of diversity policies than men.

Research How are individuals' beliefs in the sources of race/gender inequality associated Question 2: with support for workplace diversity policies?

Respondents' beliefs about the sources of inequality, particularly the role of

Key Finding: discrimination, are strong predictors of policy support. This is consistent across race/gender groups.

Research Do differences in individuals' beliefs about the sources of race/gender inequality Question 3: $\quad$ explain race and gender differences in support for workplace diversity policies?

Key Finding: Belief that discrimination causes inequality accounted for significant portions of the observed gender and racial differences in policy support.

\section{DISCUSSION}

In this study, we asked two over-arching questions: how do people feel about diversity policies and why do they feel that way? Our results shed insight on both the literature examining diversity policies in organizations and the body of research focusing more explicitly on affirmative action. Consistent with prior evidence about attitudes toward affirmative action (Bobo, 1998; Bobo and Kluegel, 1993; Steeh and Krysan, 1996), respondents' support for workplace diversity policies varies widely by gender and race, with women and non-whites espousing the highest levels of support, while whites and men report the lowest support. Also resonating with previous research on attitudes toward affirmative action policies (Boeckmann and Feather, 2007; Dawson 2001; Kane and Whipkey, 2009; Vescio et al., 2016), we found that beliefs about inequality are strong predictors of support for workplace diversity policies. The similarities between our findings and those from studies focusing explicitly on affirmative action 
indicate that the lessons from that body of literature remain highly relevant in discussions of workplace diversity policies that do not use the language of "affirmative action".

Beyond supporting previous research on affirmative action, this study also provides critical insight for researchers of workplace dynamics and inequality. Importantly, we found that beliefs about discrimination as a cause of inequality and the endorsement of structural reasons for class inequality were strong predictors of individuals' support for diversity policies. In light of previous research reporting that employee support is crucial for the success of diversity programs (Dobbin, Schrage, and Kalev, 2015), these findings provide guidance for workplace managers aiming to run successful diversity initiatives. One effective way to foster support for diversity policies among employees is to inform them about the role of discrimination and social structures in patterns of gender, race, and class inequality. Building workplace consciousness around the role of discrimination in patterns of inequality will also reduce gender/race differences in policy support - as our study showed that these beliefs were a major reason why whites and men espoused less support for workplace policies than non-whites and women.

Consistent with the centrality of beliefs in discrimination and the structural causes of class inequality, we also found that respondents are more supportive of race-based diversity policies when justified to address discrimination as opposed to when they are justified to increase diversity. These findings affirm previous research showing that workplace bias towards underrepresented groups is reduced when inclusion programs are framed as being necessary to maintain legal civil rights (Williams 2017). Through justifying diversity programs as being needed to address discrimination, such policies may garner more support since discrimination is a violation of civil rights. Additionally, these types of framings may have the added benefit of bringing attention to the role discrimination plays in the underrepresentation of women and racial 
minorities in certain occupations. Increasing awareness of discrimination not only increases support of workplace diversity policies, but is also likely to improve the workplace climate for underrepresented groups.

There are at least two ways that managers can promote an understanding of discrimination in their workplaces. In this study, we found that voluntary diversity trainings were the policy that received the most support from respondents. Drawing from broad acceptance of these programs, managers may introduce the concepts of discrimination in these settings to begin to foster an awareness of this factor as a contributor to inequality. While voluntary trainings may not reach workers who are unconcerned with diversity issues, these programs have been found in previous research improve workplace diversity because they avoid the potential for negative backlash that some employees may feel when trainings are mandatory (Kalev, Dobbin, and Kelly, 2006). A second way managers can promote an awareness of discrimination is through facilitating regular discussions among employees about how social processes related to race and gender affect certain outcomes. When discussing workplace environments, for example, Banks (2016) suggests that managers directly ask employees about gender and race equity. These types of workplace conversations with employees not only encourages them to consider race/gender issues, but it also engages them in identifying problems and designing solutions.

In addition to being a primary predictor of diversity policy support, beliefs about discrimination also explained much of the gender/racial differences in policy support because non-whites and women tended to have greater beliefs in discrimination, and thus more support for diversity policies, than whites and men. By providing one answer to the question of why there exist racial/gender differences in policy support, we generated new questions regarding why women and non-whites have higher beliefs in the role of discrimination in inequality. 
Examining these questions extends beyond the scope of this study, but the results reported here provide a potential starting point for producing new hypotheses. One might speculate, for example, that the personal experience of perceived discrimination by women and non-whites may make them more likely to link discrimination to patterns of social inequality more broadly. However, there is significant evidence that members of stigmatized groups are reluctant to attribute their own negative experiences to discrimination (e.g., Crosby et al., 1986; Stangor et al., 2003; Vorauer and Kumhyr, 2001). This work suggests instead that observation or perceptions of discrimination against others in one's in-group may play a larger role in predicting beliefs about discrimination. An alternative is that, in contrast to focusing on the experiences of stigmatized groups, the differences may instead be due to the perceptions or beliefs of socially dominant groups. These groups, such as whites and men, may have self- or group-interest in downplaying the role of discrimination in inequality, since such endorsements would undermine notions that self- or group-success is due to meritocratic efforts instead of the barriers facing others.

Our work also suggests that support for different workplace policies reflects a single underlying construct. Although mean support may vary across policy type (Bielby, Krysan, \& Herring, 2014), reported support for different types of policies formed a highly reliable index. This suggests that it may be possible in future surveys to more simply measure support for workplace diversity policies, perhaps even using a single question about such policies generally. We also argue that studying support for workplace policies may be most useful when it targets employed individuals who can consider how these policies might affect their workplace. In the future, researchers might increase the ecological validity of measures of support for diversity 
policies by asking respondents to imagine the policies are being proposed in their own workplace.

\section{Limitations}

As noted earlier, this study contains important limitations due to exigencies of the data. Specifically, the ordering of policy support questions and beliefs about the sources of inequality were not randomized. Therefore, order effects may have influenced the observed association between policy support and inequality beliefs, making our findings vulnerable to type I error. To the extent possible, we performed sensitivity checks showing that policy characteristics (specifically, how policies were justified [to address discrimination/improve diversity/none]) were unrelated to responses to the inequality belief items, suggesting that order effects were not influential in our findings.

Other limitations of our work are that we did not explore all potential moderators. For example, we do not examine policy support across occupational status. Future research may further investigate how worker position in occupational standings, as well as the characteristics of specific workplaces, predict policy support. Similarly, our findings address support for policies that are typically only implemented in large workplaces with established human resource offices and intentional diversity policies.

Finally, an additional limitation is that we did not provide respondents with detailed information about each of the proposed policies before asking about their support. We do not have evidence about how respondents understood the policies as described in the survey questions. Future research could address this through in-depth interviews or focus groups to assess how respondents interpret the policies described in the survey questions. Additionally, 
future research could assess whether providing a description of each type of workplace diversity policy prior to asking about support for it affects reported support.

\section{CONCLUSION}

By analyzing support for diversity policies, we hope to shed light on some of the opportunities and constraints organizations may face when designing or implementing such initiatives. As organizations continue to invest in diversity programs, they will have more success in environments where employees link discrimination to inequality. If such an environment does not exist, workplaces can take small steps, such as implementing voluntary training programs or engaging workers in thoughtful discussions and problem solving sessions, to introduce the concept of discrimination and its role in shaping patterns of social inequality. 


\section{REFERENCES}

Arcidiacono, P., M. Lovenheim, and M. Zhu. 2015. "Affirmative action in undergraduate education." Annual Review of Economics, 7(1): 487-518.

Beaton, A. and F. Tougas. 2001. "Reactions to affirmative action: group membership and social justice." Social Justice Research, 14: 61-78.

Bielby, W. T. 2000. "Minimizing Workplace Gender and Racial Bias." Contemporary Sociology, 29: $120-129$.

Bielby, W. T. 2014. “Americans' Support for Workplace Interventions for Combating Racial and Gender Bias: The Impact of Policy Justifications and Inequality Beliefs.” Time-Sharing Experiments for the Social Sciences. (http://www.tessexperiments.org/data/bielby276.html).

Bielby, W. T., M. Krysan, and C. Herring. 2014. "Not at My Expense: How Group Interests and Inequality Beliefs Shape Americans' Views on Workplace Anti-Discrimination Interventions." Presented at 2014 Annual Meeting of the American Sociological Association.

Bobo, L. 1998. "Race, interests, and beliefs about affirmative action: unanswered questions and new directions." American Behavior Scientist, 41: 985-1003.

Bobo, L. and J. Kluegel. 1993. "Opposition to race-targeting: self-interest, stratification ideology, or racial attitudes?" American Sociological Review, 58: 443-464.

Bullock, H. E., Williams, W. R., \& Limbert, W. M. 2003. "Predicting support for welfare policies: The impact of attributions and beliefs about inequality." Journal of Poverty, 7(3): 35-56.

Boeckmann, R. J., and N.T. Feather. 2007. "Gender, Discrimination Beliefs, Group-Based Guilt, and Responses to Affirmative Action for Australian Women." Psychology of Women Quarterly, 31: 290-304.

Correll, S. J., E. L. Kelly, L.T. O'Connor, and J.C. Williams. 2014. "Redesigning, Redefining Work." Work and Occupations, 41(1): 3-17.

Cotter, D., J. M. Hermsen, and R. Vanneman. 2011. "The End of the Gender Revolution? Gender Role Attitudes from 1977 to 2008." American Journal of Sociology, 117(1): 259-289.

Crosby F., S. Clayton, O. Alksnis, K. Hemker. 1986. "Cognitive Biases in the Perception of Discrimination: The Importance of Format.” Sex Roles, 14: 637-646.

Crosby, F. J., A. Iyer, and S. Sincharoen. 2006. "Understanding affirmative action." Annual Review of Psychology, 57: 585-611.

Dawson, M. 2001. Black Visions: The Roots of Contemporary African-American Political Ideologies. Chicago, IL: University of Chicago Press.

Dobbin, F. 2009. Inventing Equal Opportunity. Princeton, NJ: Princeton University Press.

Dobbin, F., D. Schrage, and A. Kalev. 2015. "Rage Against the Iron Cage: The Varied Effects of Bureaucratic Personnel Reforms on Diversity." American Sociological Review, 80(5): 1014-1044.

Dobbin, F. and A. Kalev. 2016. "Why Diversity Programs Fail." Harvard Business Review, JulyAugust 2016.

Eagly, A. H., \& Chaiken, S. 1993. The Psychology of Attitudes. Orlando, FL, US: Harcourt Brace Jovanovich College Publishers

Edelman, L. B. 2002. "Legality and the Endogeneity of Law." Pp. 187-202 in Legality and Community: On the Intellectual Legacy of Philip Selznick, edited by Philip Selznick, 
Robert A. Kagan, Martin Krygier, and Kenneth I. Winston. New York: Rowman \& Littlefield.

Edelman, L.B., L. H. Krieger, S. R. Eliason, C. R. Albiston, and V. Mellema. 2011. "When Organizations Rule: Judicial Deference to Institutionalized Employment Structures." American Journal of Sociology, 17(3):888-954.

Edelman, L.B., C. Uggen, and H. S. Erlanger. 1999. "The Endogeneity of Legal Regulation: Grievance Procedures as Rational Myth.” American Journal of Sociology, 105(2):40654.

Ely, R. J. and D. A. Thomas. 2001. "Cultural Diversity at Work: The Effects of Diversity Perspectives on Work Group Processes and Outcomes.” Administrative Science Quarterly, 46: 229-273.

Gross, W., T. H. Stark, J. A. Krosnick, J. Pasek, G. Sood, T. Tompson, J. Agiesta, and D. Junius. 2012. "Americans' attitudes toward the Affordable Care Act: Would Better Public Understanding Increase or Decrease Favorability?” Report prepared for the Robert Wood Johnson Foundation. Downloaded at: http://www.gsood.com/research/papers/ACAKnowledgeFavorability.pdf.

Harper, S., and B. Reskin. 2005. "Affirmative Action at School and on the Job." Annual Review of Sociology, 31: 357-379.

Heilman, M. E. 2001. "Description and Prescription: How Gender Stereotypes Prevent Women's Ascent Up the Organizational Ladder." Journal of Social Issues, Vol. 57: 657-674.

Herring, C. 2009. "Does Diversity Pay?: Race, Gender, and the Business Case for Diversity." American Sociological Review, 74(2): 208-224.

Holbrook, A. L., D. Sterrett, A. Crosby, M. Stavrakantonaki, X. Wang, T. Zhao, and T. P. Johnson. Forthcoming. "Survey Experiments and Changes in Question Wording in Repeated Cross-Sectional Surveys" in Experimental Methods in Survey Research: Techniques that Combine Random Sampling with Random Assignment, edited by P. J. Lavrakas, M. W. Traugott, C. Kennedy, A. L. Holbrook, E. D. de Leeuw, and B. T. West.

Hubbard, E. E. 2004. The Diversity Scorecard: Evaluating the Impact of Diversity on Organizational Performance. Burlington, MA: Elsevier Butterworth-Heinemann.

Hunt, M. O. 2007. “African American, Hispanic, and White Beliefs about Black/White Inequality, 1977-2004.” American Sociological Review, 72(3): 390-415.

Kaiser, C., B. Major, I. Jurcevic, T. L. Dover, L. M. Brady, and J. R. Shapiro. 2013. "Presumed Fair: Ironic Effects of Organizational Diversity Structures. " Journal of Personality and Social Psychology, 104(3): 504-519.

Kalev, A. 2009. "Cracking the Glass Cages? Restructuring and Ascriptive Inequality at Work." American Journal of Sociology, 114 (6): 1591-1643.

Kalev, A. and G. Deutsch. 2018. "Gender Inequality and Workplace Organizations: Understanding Reproduction and Change" Pp. 257-269 in The Handbook of the Sociology of Gender, Second Edition, edited by B. J. Risman, C. Froyum, and W. J. Scarborough. New York: Springer Press.

Kalev, A., E. Kelly, and F. Dobbin. 2006. "Best Practices or Best Guesses? Assessing the Efficacy of Corporate Diversity Policies." American Sociological Review, 71(4): 589617.

Kane, E. W., K. J. Whipkey. 2009. "Predictors of Public Support for Gender-Related Affirmative Action: Interests, Gender Attitudes, and Stratification Beliefs." Public Opinion Quarterly, 73(2). 
Kelly, E. L., S. K. Ammon, K. Chermack, and P. Moen. 2010. "Gendered Challenge, Gendered Response: Confronting the Ideal Worker Norm in a White-Collar Organization." Gender and Society, 24(3): 281-303.

Kelly, E. L., P. Moen, and E. Tranby. 2011. "Changing Workplaces to Reduce Work-Family Conflict: Schedule Control in a White-Collar Organization.” American Sociological Review, 76(2): 265-290.

Krysan, M. 2000. "Prejudice, Politics, and Public Opinion: Understanding the Sources of Racial Policy Attitudes." Annual Review of Sociology, 26: 135-68.

Rabinowitz, J., D. Sears, J. Sidanius, and J. Krosnick. 2009. "Why Do White Americans Oppose Race-Targeted Policies? Clarifying the Impact of Symbolic Racism." Political Psychology, 30(5): 805-828.

Scarborough, W. J. 2017. "The [Human Resource Management] Revolution Will Not Be Televised: The Rise and Feminization of Human Resource Management and Labor Force Equity." Social Currents, 4(5): 448-461.

Sears, D. O., J. Sidanius, and L. Lawrence Bobo, eds. 2000. Racialized politics: The debate about racism in America. Chicago, IL: University of Chicago Press.

Sears, D. O., C. Van Laar, M. Carrillo, and R. Kosterman. 1997. "Is It Really Racism? The Origins of White Americans' Opposition to Race-Targeted Policies." The Public Opinion Quarterly, 61(1): 16-53.

Shteynberg, G., M. Leslie, A. Knight, and D. Mayer. 2011. "But Affirmative Action hurts Us! Race-related beliefs shape perceptions of White disadvantage and policy unfairness." Organizational Behavior and Human Decision Processes, 115: 1-12.

Sidanius, J., F. Pratto, and L. Bobo. 1996. "Racism, Conservatism, Affirmative Action, and Intellectual Sophistication: A Matter of Principled Conservatism or Group Dominance?" Journal of Personality and Social Psychology, 70(3): 476-490.

Sniderman, P., and E. Carmines. 1997. Reaching Beyond Race. Cambridge, MA: Harvard University Press.

Sniderman, P., G. C. Crosby, and W. G. Howell. 2000. “The Politics of Race.” In D. O. Sears, J. Sidanius, and L. Bobo (Eds.), Racialized Politics, pp. 236-279. Chicago, IL: University of Chicago Press.

Snyder, M., and Swann, W. B. 1976. "When actions reflect attitudes: The politics of impression management." Journal of Personality and Social Psychology, 34(5), 1034.

Stangor C., J. K. Swim, G. B. Sechrist, J. DeCoster, K. L. Van Allen, A. Ottenbreit. 2003. “Ask, Answer, and Announce: Three Stages in Perceiving and Responding to Discrimination." European Review of Social Psychology, 14: 277-311.

Steeh, C. and M. Krysan. 1996. "The Polls-Trends: Affirmative Action and the Public, 19701995.” Public Opinion Quarterly, 60(1): 128-158.

Tesler, M. 2012. "The Spillover of Racialization into Health Care: How President Obama Polarized Public Opinion by Racial Attitudes and Race." American Journal of Political Science, 56(3): 690-704.

Tuch, S., and M. Hughes. 2011. "Whites' Racial Policy Attitudes in the Twenty-First Century: The Continuing Significant of Racial Resentment." The Annals of the American Academy of Political and Social Science, 63: 134-152.

Vescio, T. K., A. Cuddy, F. Crosby, and K. Weaver. 2016. "Racism, Causal Explanations, and Affirmative Action.” In Political Psychology: New Explorations, edited by J. A. Krosnick, I-C. A. Chiang, and T. H. Stark. Routledge. 
Vorauer J. D. and S. M. Kumhyr. 2001. "Is This about You or Me? Self-Versus Other-Directed Judgments and Feelings in Response to Intergroup Interaction." Personality and Social Psychology Bulletin, 27: 706-719.

Williams, J.B. 2017. "Breaking Down Bias: Legal Mandates vs. Corporate Interests." Washington Law Review 92: 1473-1513.

Wynn, A. T. and S. J. Correll. 2018. "Combating Gender Bias in Modern Workplaces” Pp. 509521 in The Handbook of the Sociology of Gender, Second Edition, edited by B. J. Risman, C. Froyum, and W. J. Scarborough. New York: Springer Press. 


\section{Appendix}

Appendix Table 1: Sensitivity Check, Mean Beliefs About Inequality Across Randomly Varying Policy Characteristics

\begin{tabular}{lccc}
\hline & \multicolumn{3}{c}{ Policy Justification } \\
\cline { 2 - 4 } & $\begin{array}{c}\text { To } \\
\text { To Address } \\
\text { Iiscrimination }\end{array}$ & $\begin{array}{c}\text { No } \\
\text { Diversity }\end{array}$ & Justification \\
\hline Mean Levels: Beliefs About Inequality & & \\
$\quad$ Gender Target & & & \\
$\quad$ Discrimination & 0.637 & 0.665 & 0.669 \\
$\quad$ Educational Opportunity & 0.455 & 0.471 & 0.508 \\
$\quad$ Training & 0.489 & 0.539 & 0.519 \\
Race Target & & & \\
$\quad$ Discrimination & 0.554 & 0.552 & 0.512 \\
$\quad$ Educational Opportunity & 0.591 & 0.536 & 0.514 \\
$\quad$ Training & 0.613 & 0.569 & 0.614 \\
\hline
\end{tabular}

Note: No significant differences observed 
Appendix Table 2: Descriptives

\begin{tabular}{|c|c|c|c|c|}
\hline Variable & Mean & SD & Min & Max \\
\hline \multicolumn{5}{|l|}{ Gender Target } \\
\hline Support for Gender-Based Policies & 0.60 & 0.19 & 0 & 1 \\
\hline Belief in Discrim as Source of Ineq. & 0.66 & 0.30 & 0 & 1 \\
\hline Belief in Educ. Opp. as Source of Ineq. & 0.48 & 0.33 & 0 & 1 \\
\hline Belief in Training as Source of Ineq. & 0.52 & 0.32 & 0 & 1 \\
\hline \multicolumn{5}{|l|}{ Race Target } \\
\hline Support for Race-Based Policies & 0.58 & 0.20 & 0 & 1 \\
\hline Belief in Discrim as Source of Ineq. for Blacks & 0.54 & 0.35 & 0 & 1 \\
\hline Belief in Educ. Opp. as Source of Ineq. for Blacks & 0.55 & 0.35 & 0 & 1 \\
\hline Belief in Training as Source of Ineq. for Blacks & 0.60 & 0.31 & 0 & 1 \\
\hline \multicolumn{5}{|l|}{ Variables Without Target Randomization } \\
\hline Belief in Structural Reasons for Inequality & 0.69 & 0.23 & 0 & 1 \\
\hline Political Conservatism & 0.48 & 0.25 & 0 & 1 \\
\hline Household Income & $12.37(\$ 53,700)$ & 4.02 & 1 (Less than $\$ 5,000)$ & $19(\$ 175 \mathrm{k}+)$ \\
\hline Education & 10.37 (Some College) & 1.810701 & 1 (no education) & $\begin{array}{r}14 \text { (Prof. or Doctorate } \\
\text { Degree) }\end{array}$ \\
\hline \multicolumn{5}{|l|}{ Respondent Race/Gender Composition } \\
\hline Women & $46 \%$ & & & \\
\hline Men & $54 \%$ & & & \\
\hline Black & $28 \%$ & & & \\
\hline Latino/a & $29 \%$ & & & \\
\hline White & $43 \%$ & & & \\
\hline
\end{tabular}

